RESEARCH ARTICLE

\title{
Response of endemic Mangifera zeylanica (Blume) Hook. f. fruit to common postharvest pathogens of cultivated mango (Mangifera indica L.) fruit in Sri Lanka
}

\section{K.O.L.C Karunanayake* and N.K.B Adikaram}

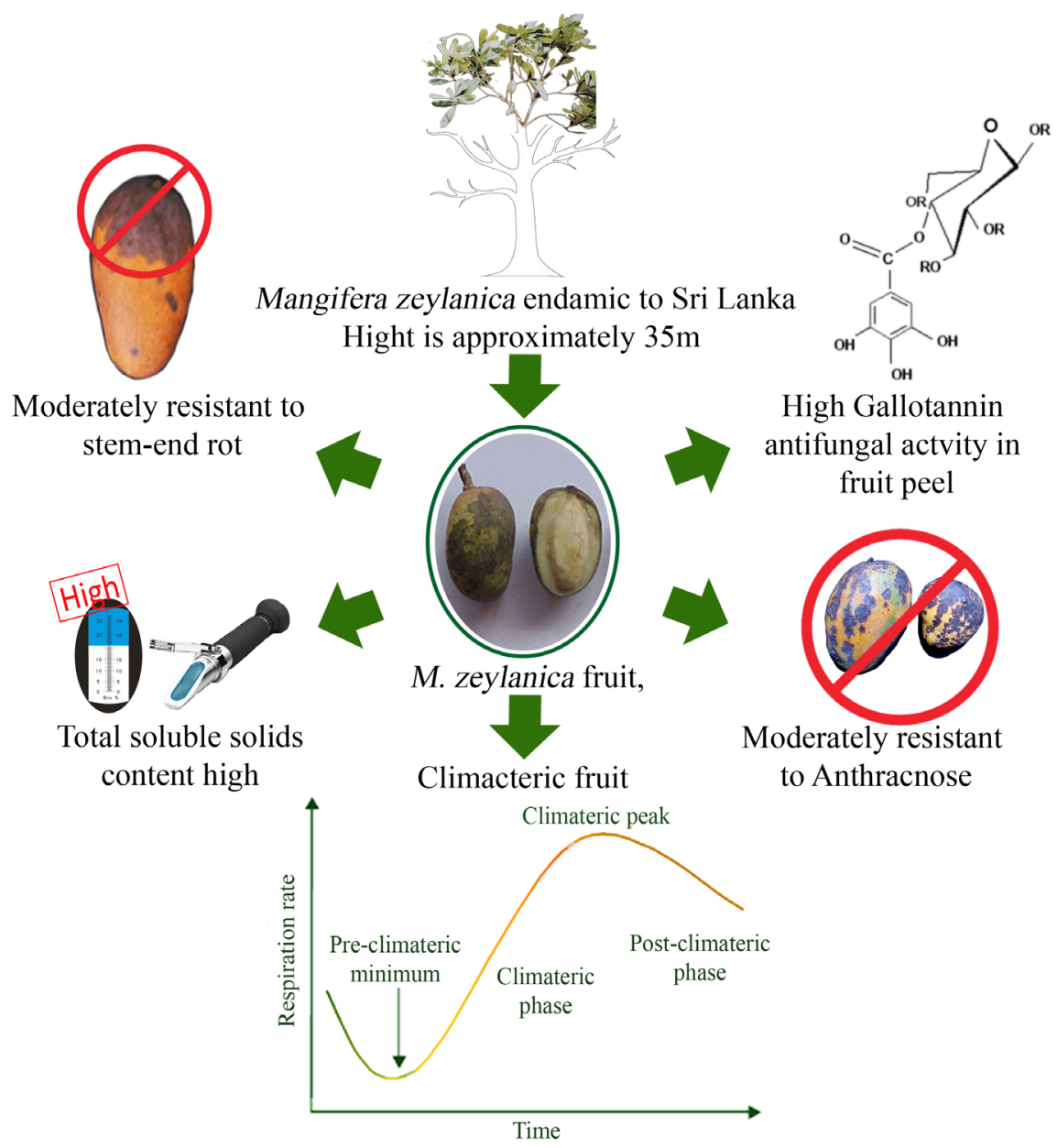

\section{Highlights}

- Mangifera zeylanica fruit shows a climacteric pattern of respiration.

- M. zeylanica fruit is moderately resistant to Colletotrichum spp. and Lasiodiplodia sp. causing anthracnose and stem-end rot, respectively.

- Peel of unripe $M$. zeylanica fruit contains antifungal gallotannins that are present in the fruit peel of $M$. indica, contributing to its constitutive defences. 


\title{
RESEARCH ARTICLE
}

\section{Response of endemic Mangifera zeylanica (Blume) Hook. f. fruit to common postharvest pathogens of cultivated mango (Mangifera indica L.) fruit in Sri Lanka}

\author{
K.O.L.C Karunanayake ${ }^{1, *}$ and N.K.B Adikaram ${ }^{2}$ \\ ${ }^{1}$ Department of Botany, Faculty of Natural Sciences, The Open University of Sri Lanka, Nawala, Sri Lanka. \\ ${ }^{2}$ National Institute for Fundamental Studies, Hantana, Kandy, Sri Lanka.
}

Received: 14/11/2019; Accepted: 15/01/2021

\begin{abstract}
Two species of Mangifera are found in Sri Lanka, the cultivated Mangifera indica L. and the endemic M. zeylanica (Blume) Hook.f. [Et-amba (S)]. Mangifera indica is a climacteric fruit, susceptible to infection by many fungal pathogens, causing postharvest diseases at ripe stage. Among them, Colletotrichum spp. and Lasiodiplodia theobromae that cause anthracnose and stem-end rot disease respectively, are considered the most destructive postharvest pathogens in ripe mangoes. Harvested fruit of M. zeylanica also showed a climacteric pattern of respiration and the pulp was sweet to taste, with acceptable TSS value for mango fruit. The present study investigated the resistance or susceptibility of the fruit of endemic M. zeylanica to these two pathogens. Artificial inoculation of fruits with C. gloeosporioides and $L$. theobromae separately, produced anthracnose as well as stem-end rot symptoms respectively, showing that $M$. zeylanica fruits are susceptible to the pathogens. However, considering the pattern and the extent of disease development, M. zeylanica fruits can be considered moderately resistant to both pathogens. Alternaria sp., Pestalotiopsis sp., Lasiodiplodia theobromae, Curvularia sp. and Neofusicoccum sp. were frequently isolated from the pedicel and the stem-end region of healthy fruits of M. zeylanica at harvesting maturity. However, Colletotrichum species could not be isolated from either the pedicel or the stemend region of M. zeylanica. TLC-Cladosporium bioassay of
\end{abstract}

peel extract of the unripe M. zeylanica fruit resulted in a large inhibition zone at $R_{f} 0.00$ which corresponded with antifungal gallotannins contributing to the constitutive defences of $M$. indica fruit against invading pathogens.

Keywords: Mangifera zeylanica; endemic; postharvest; anthracnose; stem-end rot; mango fruit.

\section{INTRODUCTION}

The genus Mangifera (Family Anacardiaceae) consists of 69 species of Asian origin (Nakasone and Paull 1998) and all species do not bear edible fruit. The mango, Mangifera indica L., is the best known and most widely cultivated genus in the world. Mangifera zeylanica (B1.) Hook f. is among the few species in the genus that bear edible fruit. Mangifera zeylanica is an endemic species to Sri Lanka and locally known as Et-amba (S) (Dassanayake and Fosberg, 1983). Although fruits of Et-amba are edible and the whole plant has medicinal properties, it is not cultivated due to the exceptionally smaller size (Fig. 1) (3 - $4 \mathrm{~cm}$ long) of the fruit (Dassanayake and Fosberg, 1983) and proportionately larger seed which occupies most of the fruit volume (Medagoda and Jayawardena, 1997).

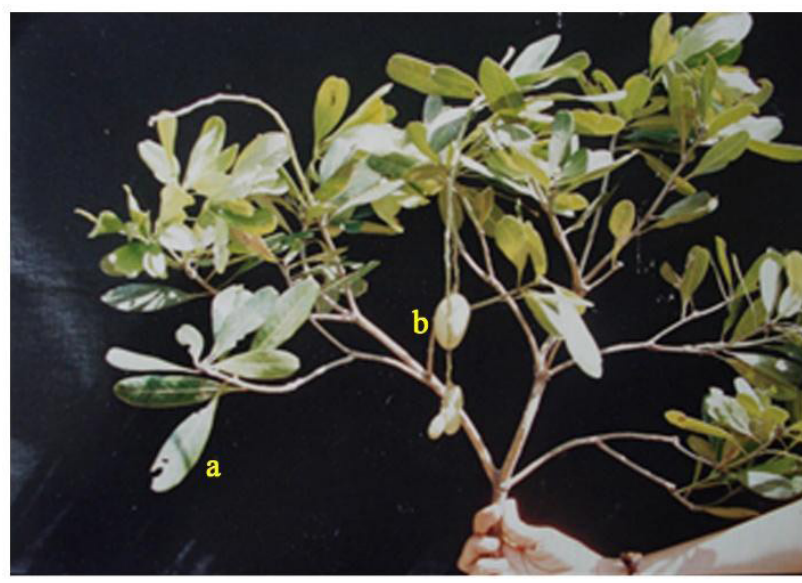

A

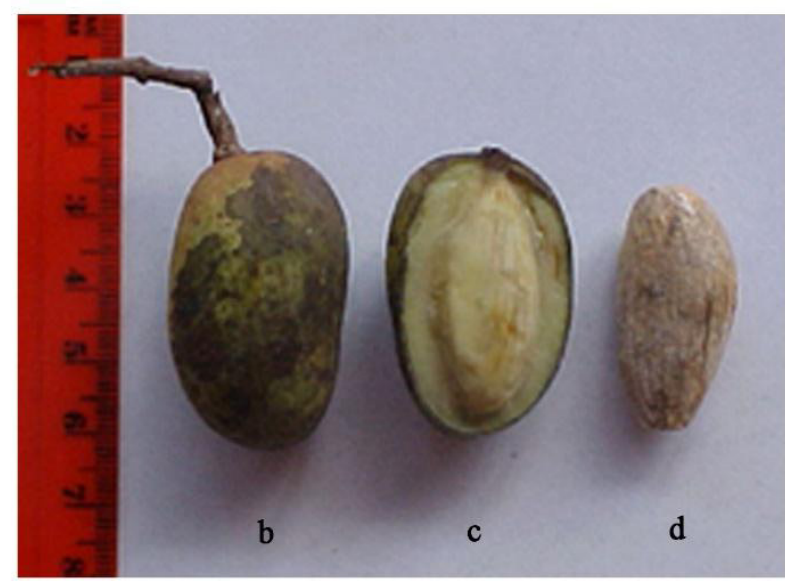

B

Figure 1: (A) Twig of M. zeylanica with (a) lanceolate leaves (5 - $8 \mathrm{~cm}$ in length) arranged spirally, and (B) mature fruit of M. zeylanica, (b) fully mature fruit (4 cm in length), (c) longitudinal section of the fruit showing the seed and flesh, (d) seed of the fruit. 
Weeraratne et al. (2005) carried out a study to establish the evolutionary relationship among eleven selected local $M$. indica cultivars and M. zeylanica using Random Amplified Polymorphic DNA (RAPD) markers. The dendrogram obtained showed four cultivated varieties of $M$. indica and the endemic $M$. zeylanica, that are all regular fruit bearers, grouped together. Based on the 2012 National Red List of Sri Lanka (MOE, 2012), M. zeylanica is categorized in the National conservation status 'Least Concerned' and as 'Vulnerable' according to Global Conservation status (Ariyarathne et al., 2017).

Bark extracts of $M$. zeylanica show strong anti-cancer properties (Ediriweera et al., 2016 a, b; 2017) and leaf extracts possess antimicrobial properties against certain pathogenic (human) bacteria and fungi (Dhanasiri et al., 2014). Ethanol and $70{ }^{\circ} \mathrm{C}$ water extracts of leaves are effective against many microorganisms including Methiciline-resistant Staphylococcus aureus (MRSA), Enterococcus faecalis, Pseudomonas aeruginosa and nonalbicans Candida (Dhanasiri et al., 2014). Further, it has been shown that endophytic fungi colonizing leaves of $M$. zeylanica secrete potent antimicrobial substances against selected (human) pathogenic bacteria as well (Senevirathna et al., 2015). However, there are no reports on diseases and the fungal pathogens causing diseases to M. zeylanica fruit. There is a common belief that certain endemic species or 'wild varieties' are more resistant to disease than cultivated varieties, yet no studies have been done so far to establish its validity, especially with M. zeylanica. The present study investigated the response of $M$. zeylanica fruits to major fungal pathogens causing two most common postharvest fruit diseases, anthracnose and stem-end rot (SER), in mango ( $M$. indica). Mango anthracnose was earlier known to be caused by Colletotrichum gloeosporioides Penz and Sacc. (Dodd et al., 1991; Arauz, 2000). More recent reports indicated that in Sri Lanka the mango anthracnose is caused by several species including Colletotrichum asianum, $C$. siamense, C. fruticola and C. tropicale, all belonging to the Colletotrichum gloeosporioides species complex (Komala Withanage et al., 2014). The stem-end rot of mango is caused mainly by Lasiodiplodia theobromae (Pat.) Griff et Maubl. in tropical Asia (Johnson et al., 1993) and Dothiorella spp., Phomopsis mangiferae, Pestalotiopsis sp. and Cytosphaera mangiferae are also known as causal agents (Johnson et al., 1992). Lasiodiplodia theobromae, Dothiorella spp., $C$. gloeosporioides, Phomopsis mangiferae and Pestalotiopsis mangiferae have been identified as SER pathogens of mango, in Sri Lanka, while a study using ITS sequence data has reported two new Ascomycota species from the local cultivar 'Karuthacolomban', namely: Xylaria sp. and Nodulisporium sp. (Karunanayake et al., 2014; Ekanayake et al., 2019).

The present study was carried out to investigate the resistance or susceptibility of $M$. zeylanica to anthracnose and stem-end rot in ripe fruits, and also to assess the level of preformed antifungal activity in fruit peel of $M$. zeylanica, in comparison with three local mango $(M$. indica L.) cultivars showing variable susceptibility to the two postharvest fungal diseases considered in the study. 'Karuthacolomban' is more resistant to anthracnose disease but highly susceptible to SER whereas the cultivar 'Willard' is highly susceptible to anthracnose while more resistant to SER. The cultivar 'Rata' ('Vellacolomban') is moderately susceptible to both diseases (Karunanayake et al., 2014).

\section{MATERIALS AND METHODS}

\section{Fruits}

Three cultivars of $M$. indica, 'Karuthacolomban' (KC), 'Willard' and 'Rata' were used along with M. zeylanica for inoculation studies. The fruits of $M$. indica were bought from a wholesale market in 'Kiribath kumbura' (7 $7^{\circ} 7^{\prime}$ " $\mathrm{N}$ and $80^{\circ} 57^{\prime} \mathrm{E}$ ) (Kandy District, Central Province/ CP) which receives fruits regularly from orchards in Dambulla,

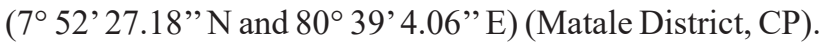
Unripe fruits at harvest maturity, selected for the study, had been harvested on the same day. Mature, unripe fruits of M. zeylanica were hand-picked (by employing climbers) from trees of 'Raththota' area ( $7^{\circ} 30^{\prime} 48^{\prime}$ ' N, $80^{\circ} 39^{\prime}$ ' 42 '” E) (Matale District, CP). All fruits selected for studies were healthy and blemish free. Fruits were transported to the Plant Pathology laboratory at the University of Peradeniya within $8 \mathrm{~h}$ of harvest and taken for studies within $24 \mathrm{~h}$. All fruits were washed in tap water and allowed to dry under ambient conditions, $28 \pm 2{ }^{\circ} \mathrm{C}$, in the laboratory.

\section{Naturally occurring fungi in fruit of M. zeylanica - isolation studies}

Small square segments $\left(0.5 \times 0.5 \mathrm{~cm}^{2}\right)$ were cut from the peel at the stem-end of the healthy fruit and pieces $(0.5$ $\mathrm{cm}$ long) of the fruit pedicel were also cut from fruits of $M$. zeylanica to isolate fungi present, if any, in the outer cell layers of peel and fruit pedicel. The segments were surface sterilized in $1 \% \mathrm{NaOCl}$ (Chlorox, USA) for $3 \mathrm{~min}$, washed in sterile distilled water (SDW), cut in half (pedicel longitudinally) and transferred on to PDA in Petri dishes. The plates were incubated at $28 \pm 2{ }^{\circ} \mathrm{C}$ for 10 days for initial isolations. Ten-day old colonies from tissue segments on PDA were examined for colony morphology and under the light microscope (Olympus CX31 Microscope with Digital Camera DP20) for conidial morphology and identified to genus level with the aid of CMI descriptions. Identified fungi were sub-cultured on fresh PDA and maintained as pure cultures for 4 to 6 weeks to observe structures such as pycnidia.

Symptoms of diseases which developed as natural infections on harvested $M$. zeylanica fruits were also recorded. The causal agents of these diseases were isolated from symptomatic fruit peel tissues as described above.

For isolation of endophytic fungi, tissue segments were aseptically cut from the inner layers of the peel and from the outer pulp, just below the peel. Visually healthy, unripe fruits were used for isolation studies. These segments were subjected to triple sterilization, by first placing in $70 \%$ ethanol for $30 \mathrm{sec}$, then in $1 \% \mathrm{NaOCl}$ for $2 \mathrm{~min}$ and again in $70 \%$ ethanol for $15 \mathrm{sec}$. (Petrini, 1986). The segments were removed using sterile forceps, cut into halves and transferred aseptically on to PDA in Petri dishes. The plates were incubated at room temperature $\left(28 \pm 2{ }^{\circ} \mathrm{C}\right)$. 


\section{Fruit inoculations}

\section{Anthracnose pathogen}

A suspension of conidia of C. gloeosporioides was prepared by pouring SDW into Petri plates and scraping the mycelium of a two-week-old pure culture, using a sterile glass rod, then filtering through glass wool (Karunanayake et al., 2015). The concentration was adjusted to $10^{5}$ conidia/ $\mathrm{ml}$. Three drops $(20 \mu \mathrm{l})$ were placed along the long axis of each fruit and the inoculated fruits were maintained in moist chambers to provide necessary humidity for conidia germination $\left(100 \% \mathrm{RH}\right.$ and $\left.28 \pm 2{ }^{\circ} \mathrm{C}\right)$. When symptoms appeared, disease severity was assessed by measuring the diameter of the lesion along 2 axes right angles to each other and calculating the average diseased area. Measurements were taken daily for 7 days after inoculation.

\section{Stem-end rot pathogen}

The fruit pedicel was removed and the peel at the stem end of each fruit was slightly damaged by scraping with a sterile scalpel (Nisansala et al., 2015). A mycelial plug of L. theobromae was placed with the mycelium touching the freshly cut surface of the stalk-end. The inoculated fruits were incubated in moist chambers at $100 \% \mathrm{RH}$ and $28 \pm 2$ ${ }^{\circ} \mathrm{C}$. The mycelia plug was removed after $24 \mathrm{~h}$ and the fruits were returned to the moist chambers. When the symptoms appeared, the severity of the stem-end rot was measured daily by tracing the affected area onto a transparent graph papers with $1 \mathrm{~mm}^{2}$ squares and recording the number of squares occupied by the disease area. Measurements were taken for 7 days after inoculation.

\section{Data analysis}

Each experiment consisted of 8 replicate fruits from each cultivar and the trial was carried out twice. Data of the two trials were pooled and the variance was analyzed as a completely randomized design at the $5 \%$ probability level with the software package SAS ver.6.12.

\section{Antifungal activity of the peel of M. zeylanica}

Thin (1 - $3 \mathrm{~mm})$ peels were obtained from mature unripe fruits of $M$. zeylanica and extracted into dichloromethane and methanol $(1: 1 \mathrm{v} / \mathrm{v})$ using vacuum infiltration (Karunanayake et al., 2011). Aliquot $(100 \mu \mathrm{L})$ of crude peel extract equivalent to $0.5 \mathrm{~g}$ fresh peel tissue was spotted on TLC, developed with chloroform:methanol:ethyl acetate $(90: 5: 5 \mathrm{v} / \mathrm{v} / \mathrm{v})$ and subjected to a thin layer chromatography bioassay with Cladosporium cladosporioides as the assay organism. Inhibition zones corresponding to antifungal activity were observed after $72 \mathrm{~h}$ incubation in moist chambers (Karunanayake et al., 2011).

\section{Rate of respiration}

Twenty-four freshly harvested fruits of uniform maturity were taken for the study. The rate of respiration and variation in total soluble solids (TSS) were measured daily using three fruits for up to 8 days after harvest. Each fruit which was to be used for the study on a given day was weighed and then placed inside an air-tight glass vessel, and the vessel was sealed for one hour prior to the measurement of $\mathrm{CO}_{2}$. The composition of air in the vessel was assessed using $\mathrm{CO}_{2}$ measurements obtained from a gas analyzer (280 Combo gas analyzer). The rate of respiration was calculated using the highest $\mathrm{CO}_{2}$ reading using the equation below (Kays, 1991).

Rate of respiration $=$

\section{$\% \mathrm{CO}_{2} \times$ Volume of vessel - volume of fruit $(\mathrm{mL})$}

Time of incubation $(\mathrm{h}) \times$ fresh weight of fruit $(\mathrm{g})$

The weight of the fruit was used as the volume, assuming that the fruit density to be equal to that of water. Three fruits were used daily, and the average value was calculated.

\section{Total soluble solids content in pulp}

The middle one-third of fruit mesocarp was obtained separately from each of the three fruits on days 3 to 7 after harvest. The mesocarp tissues obtained for each day were combined and blended (ULTRATURRAX omnimixer $\circledR$, T25 basic) for $1 \mathrm{~min}$. A portion of this pulp mixture (approximately $5 \mathrm{~g}$ ) was then centrifuged at $3000 \mathrm{~g}$ (Sigma $3 \mathrm{~K} 30$ Laboratory centrifuge) for $10 \mathrm{~min}$. A drop $(20 \mu \mathrm{L})$ of the juice extracted from the pulp by this process was placed on the glass prism of a hand-held refractometer (Leica, Model 10430) and the ${ }^{\circ}$ Brix reading at room temperature $\left(28 \pm 2{ }^{\circ} \mathrm{C}\right)$ was obtained (Samane et al., 2012).

\section{RESULTS AND DISCUSSION}

\section{Naturally occurring fungi in fruit peel of M. zeylanica.}

Isolations made from healthy stem-end area showed the presence of several Botryosphaeriaceae species; Lasiodiplodia theobromae (Syn. Botryodiplodia theobromae) (Fig. 2 a, b), and Neofusicoccum sp. (figure not provided). Isolations from healthy fruit pedicel showed the presence of Alternaria sp., Neofusicoccum sp., Curvularia sp. (figures not provided) and Pestalotiopsis sp. (Fig. 2 c, d), sp. Endophytes were not isolated from the internal fruit tissue of M. zeylanica. Lasiodiplodia theobromae, Dothiorella spp., C. gloeosporioides, Phomopsis mangiferae and Pestalotiopsis mangiferae have been identified as the most frequently observed SER pathogens of mango, in Sri Lanka. (Karunanayake et al., 2014; Ekanayake et al., 2019). Stem-end rot (SER) symptoms developed from natural infections in $M$. zeylanica fruits during ripening (Fig. 3). Typical soft, pale brown rots originated at the stem-end and extended towards the stylar-end. It is noteworthy that in M. zeylanica, the SER did not develop covering a larger portion of the fruit within 4 to 5 days and the pulp or mesocarp tissue was not completely softened and macerated as seen in the cultivar 'Karuthacolomban'. Isolations of the diseased tissue on to PDA showed the growth of a greyish white colony which darkened with time to become a dark grey-black following incubation at room temperature $\left(28 \pm 2{ }^{\circ} \mathrm{C}\right)$. Hard raised structures, which were identified as pycnidia developed on the surface of the colony after 28 days incubation at room temperature. Pycnidia development enhanced when the cultures were exposed to near UV light for a period of $12 \mathrm{~h}$ daily. When the pycnidia were crushed and observed under the light microscope, dark brown, two- 


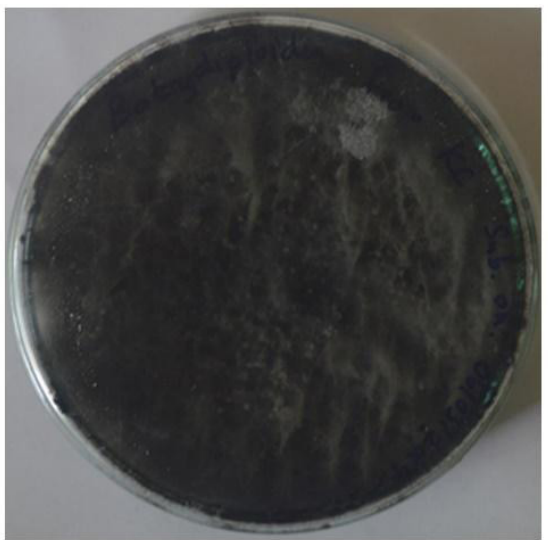

(a)

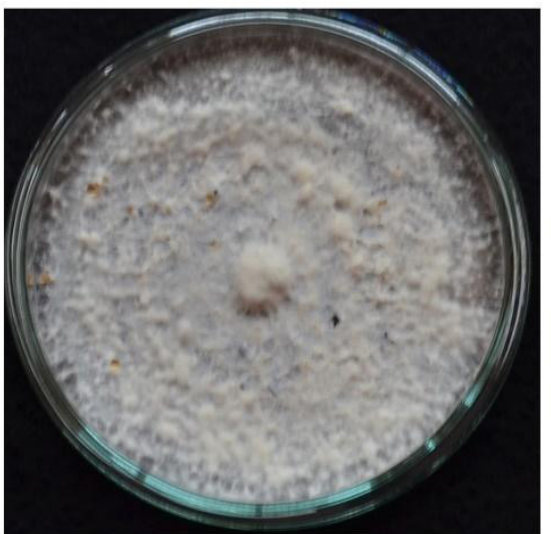

(c)

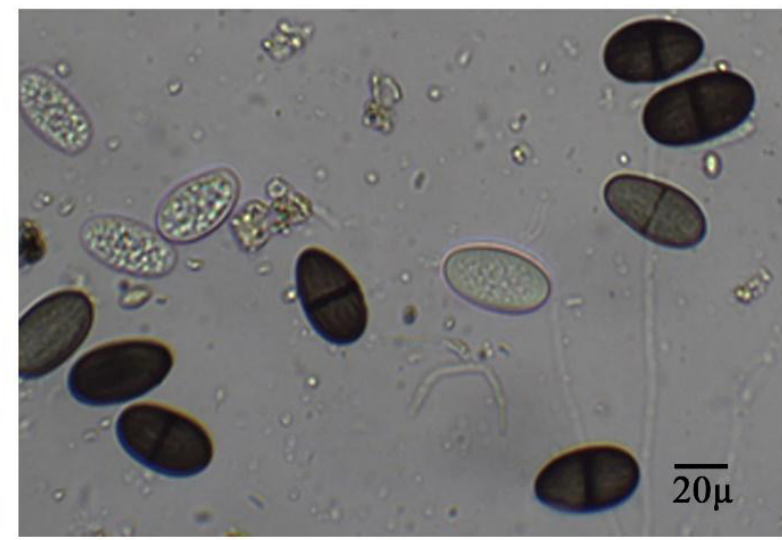

(b)

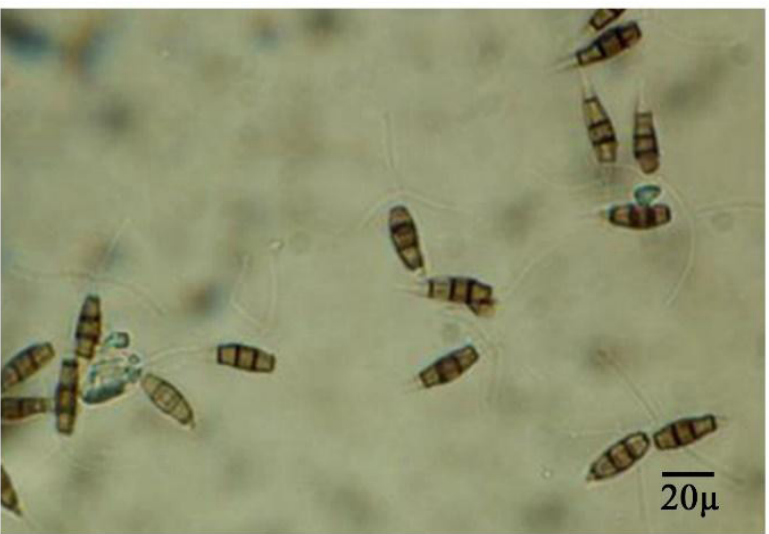

(d)

Figure 2: Two fungi isolated from the fruit of M. zeylanica, (a) A colony of $L$. theobromae grown on PDA, (b) Mature conidia of $L$. theobromae, (c) Pestalotiopsis sp. colony on PDA and, (d) Conidia of Pestalotiopsis sp.

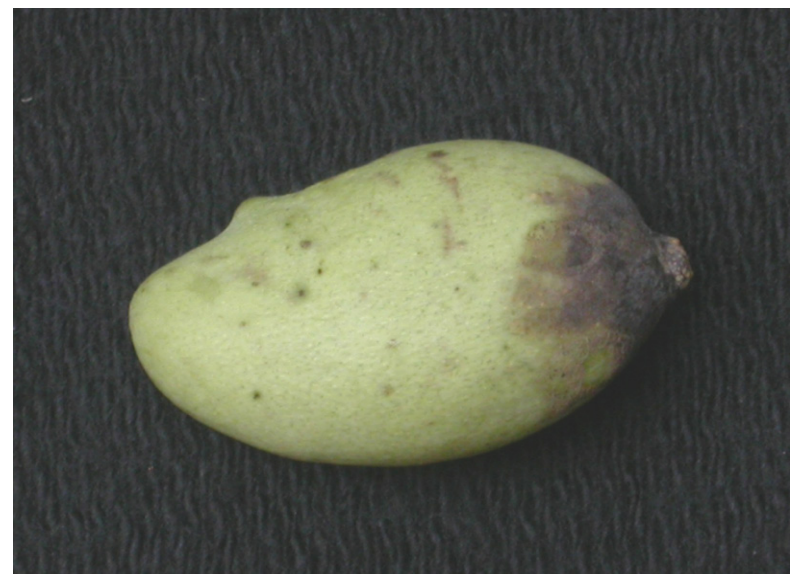

Figure 3: Fruit of M. zeylanica with characteristic symptoms of stem-end rot, from natural infections.

celled conidia were seen. Based on colony characteristics and the morphology of conidia, the causal organism was confirmed as L. theobromae [Fig 2 (a), (b)]. Based on literature and phylogenetic studies the genus Lasiodiplodia is reported to be the dominant genus associated with mango diseases worldwide (Trakunyincharoen et al., 2014). Further, L. theobromae is reported as the most dominant of the species from the most number of mango growing countries in association with mango diseases world-wide (Trakunyingcharoen et al., 2014) and is also the most common causal agent for SER in tropical Asia (Johnson et al., 1993).
Neofusicoccum sp. and Pestalotiopsis sp. are reported to be present in stem-end rots (Johnson et al., 1992) and Alternaria sp. is a known mango fruit pathogen (Droby et al., 1986) although not associated with postharvest disease in Sri Lanka. Seven taxa of Botryosphaeriaceae are reported to be associated with SER in Brazil, Neofusicoccum sp., Botryosphaeria dothidea being among the reported. Pseudofusicoccum stromaticum and B. dothidea were the most frequently isolated while Neofusicoccum parvum and Neoscytalidium dimidiatum were the most virulent (Marques et al., 2013). However, it is interesting to note that Colletotrichum spp., known to form quiescent infections 
in mango (Arauz, 2000) and cause anthracnose in ripe fruit, were not isolated from M. zeylanica. It could be that Colletotrichum spp. are not naturally found in this locality or that other microbes present as microflora on the fruit's surface out-compete Colletotrichum sp. for nutritional and space requirements. Anthracnose development due to natural infections was also not observed in harvested fruits of $M$. zeylanica, however, fruits were susceptible to the disease and expressed characteristic symptoms when inoculated.

\section{Inoculation studies}

\section{Anthracnose pathogen}

Mangifera zeylanica fruits developed anthracnose disease following artificial inoculation. In fruits of cultivar 'Willard', measurable anthracnose lesions appeared five days after inoculation and after six days in fruits of the cultivars 'Rata' and M. zeylanica. Anthracnose symptoms appeared in 'Karuthacolomban' fruits only eight days after of inoculation (Fig. 4). There was no significant difference among the time taken for development of anthracnose lesions in fruits among M. zeylanica, 'Karuthacolomban' and 'Rata'. However, all three cultivars developed significantly $(\mathrm{P}<0.05)$ smaller lesions of anthracnose upon inoculation and hence are significantly more resistant to anthracnose when compared with 'Willard'.

\section{Stem-end rot pathogen}

Disease development commenced two days after inoculation in all the considered cultivars. The lesion areas of 'Rata', Willard' and M. zeylanica were not significantly different from each other. Stem-end rot area was significantly higher $(\mathrm{P}<0.05)$ in cultivar 'Karuthacolomban' compared to the other three cultivars used in the study from disease initiation onwards (Fig 5). Mangifera zeylanica is significantly resistant to SER when compared with 'Karuthacolomban' $(\mathrm{P}<0.05)$.

It is significantly less susceptible to anthracnose when compared with the highly susceptible 'Willard' and significantly less susceptible to SER when compared with highly susceptible 'Karuthacolomban'. Therefore, its resistance seems comparable with cultivars such as 'Rata', and 'Dilpasan' (Karunanayake et al., 2014) which show moderate resistance to both diseases. The study confirms that $M$. zeylanica is moderately resistant to both SER and anthracnose diseases.

\section{Antifungal activity in the fruit peel of $M$. zeylanica}

The crude peel extract of M. zeylanica, when spotted on TLC and subjected to the Cladosporium bioassay, show the presence of antifungal activity (Fig. 6). A clear large inhibition zone was present in the peel extract of $M$. zeylanica at $\mathrm{R}_{\mathrm{f}} 0.00$. This zone of inhibition was identical to that in peel extracts of $M$. indica species, at $\mathrm{R}_{\mathrm{f}} 0.00$, which constitutes gallotannins (Adikaram et al., 2010; Karunanayake et al., 2011). Additional inhibition zones were also seen at $R_{f} 0.72-0.75$ and $0.8-0.92$ which are not so prominent.

These could be due to resorcinols which are known to be antifungal compounds in unripe peel of $M$. indica fruits (Cojocaru et al, 1986; Prusky and Keen, 1993; Droby et al., 1986; Hassan et al., 2007; Karunanayake et al., 2011) and are also reported in M. zeylanica (Ediriweera et al., 2017) although not in connection with antifungal properties. The presence of Mangiferin has been reported from the bark of M. zeylanica (Herath et al., 1970) and several other polyphenols, flavonoids and halogenated constituents with anti-cancer properties (Ediriweera et al., 2016a; 2016b). The inhibition area produced by the dried peel extract, equivalent to $0.5 \mathrm{~g}$ was quite high,

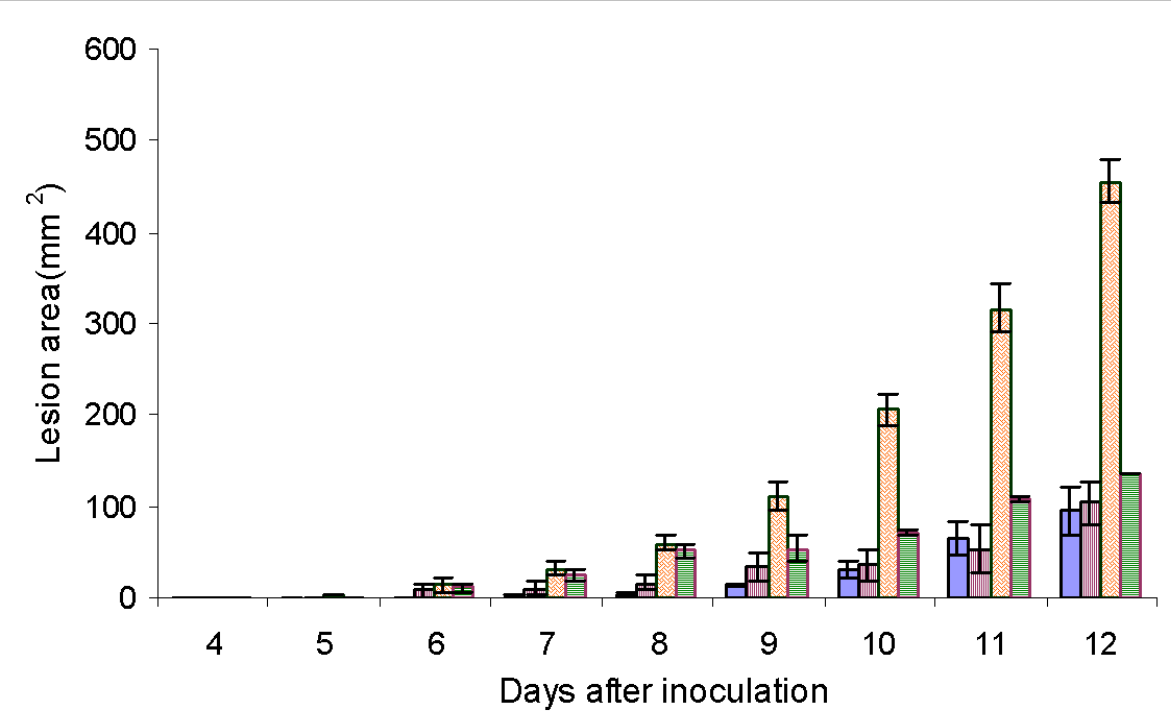

$\square$ Karuthacolomban $\square$ Rata $\square$ Willard $\square$ Etamba

Figure 4: Anthracnose disease development after inoculation, in a few M. indica cultivars; 'Karuthacolomban', 'Rata', 'Willard' and M. zeylanica ('Et-amba'). 


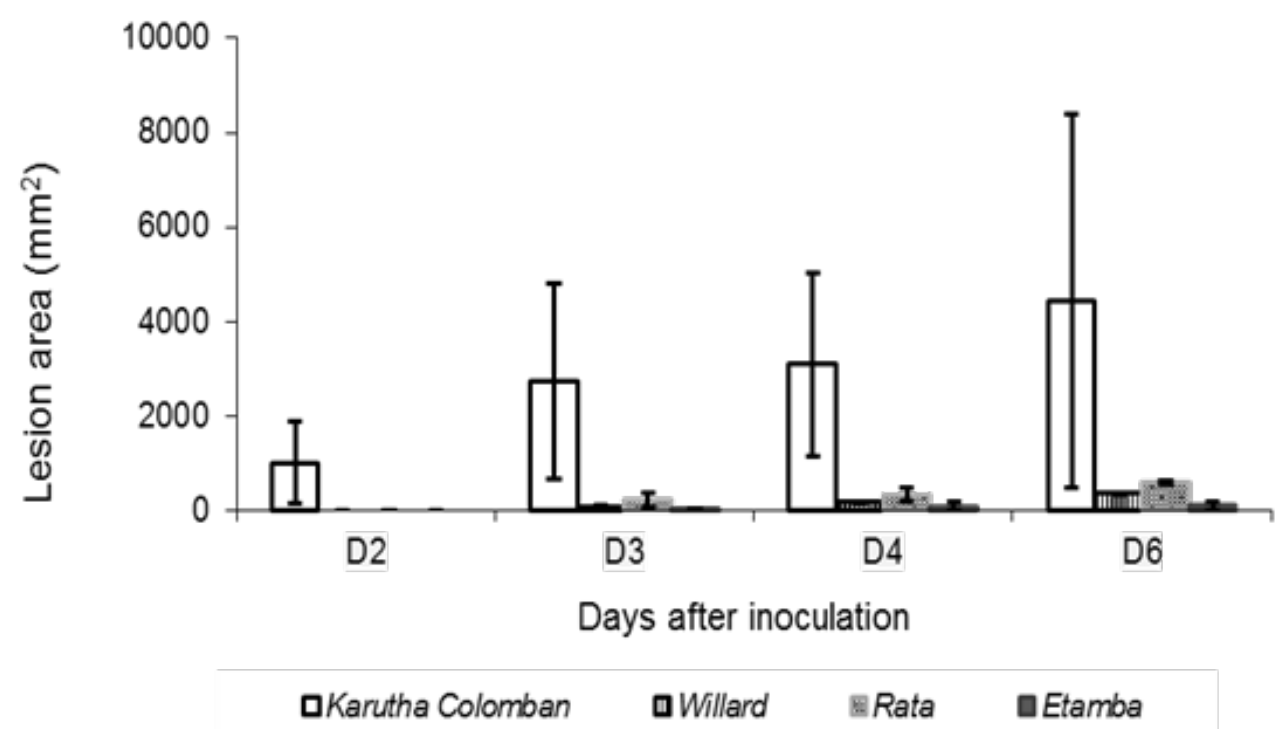

Figure 5: Stem-end rot development in selected M. indica cultivars and M. zeylanica ('Et-amba'), after inoculation with SER pathogen.

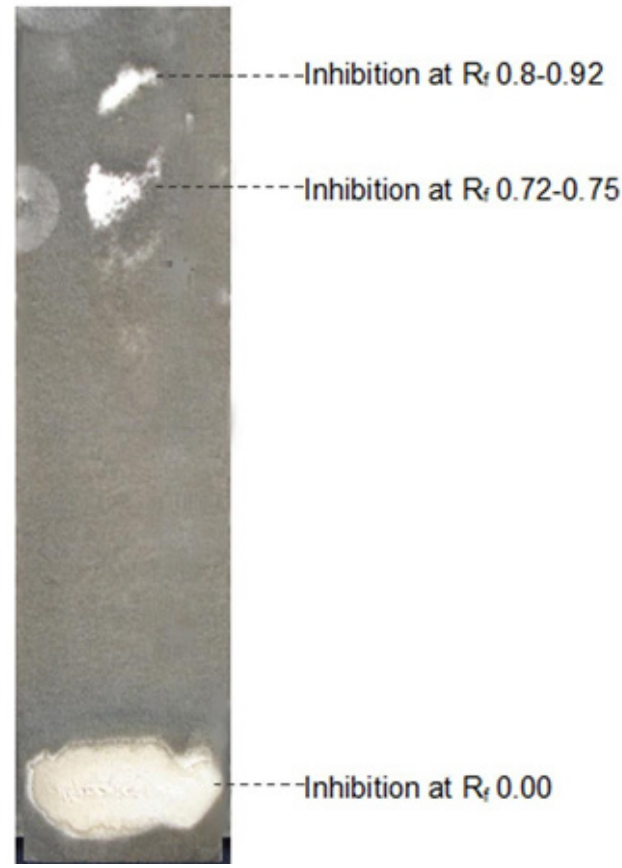

Figure 6: Thin layer chromatogram of the unripe fruit peel extract of $M$. zeylanica bio-assayed with Cladosporium cladosporioides sp.

$424 \mathrm{~mm}^{2}$, which is comparable with cultivars such as 'Gira' and 'Karuthacolomban' which are more resistant to anthracnose (Karunanayake et al., 2014). Further, it is also noteworthy that the peel of ' $M$. zeylanica' fruits also did not become yellow when ripe, as seen in anthracnose resistant 'Karuthacolomban', 'Gira' and moderately resistant 'Rata'. Gallotannins are directly fungitoxic to $C$. gloeosporioides and L. thoebromae (Adikaram et al., 2010). The presence of Gallotannins at high concentrations should contribute to the relative resistance of ' $M$. zeylanica' fruit to both anthracnose and SER diseases.

\section{Rate of respiration}

The rate of respiration of the $M$. zeylanica fruits was initially $0.1 \mathrm{CO}_{2} \mathrm{~mL}^{-1} \mathrm{~g}^{-1} \mathrm{~h}^{-1}$ then it rose to a maximum of 0.2 $\mathrm{CO}_{2} \mathrm{~mL}^{-1} \mathrm{~g}^{-1} \mathrm{~h}^{-1}$ five days after harvest and again declined to $0.125 \mathrm{CO}_{2} \mathrm{~mL}^{-1} \mathrm{~g}^{-1} \mathrm{~h}^{-1}$. Therefore, M. zeylanica appears to follow a climacteric pattern in respiration (Fig 7).

\section{Total soluble solids content in pulp}

The total soluble solids (TSS) content was initially 4.2 ${ }^{\circ}$ Brix in the unripe fruit and gradually increased to 11.2 in the ripe fruit (Fig 7). ${ }^{\circ}$ Brix value for sugar content is given as $4 \%$ for poor, $6 \%$ for average, $10 \%$ for good and $14 \%$ for excellent in mango fruit (Harrill, 1998) of $M$. indica. Therefore, it is apparent that $M$. zeylanica fruits also have comparable values and are in the range of 'good' in terms of TSS when compared with $M$. indica species.

\section{CONCLUSION}

The study confirms that the fruit of $M$. zeylanica is moderately resistant to both postharvest anthracnose and SER diseases that affect the cultivated mango fruits in Sri 


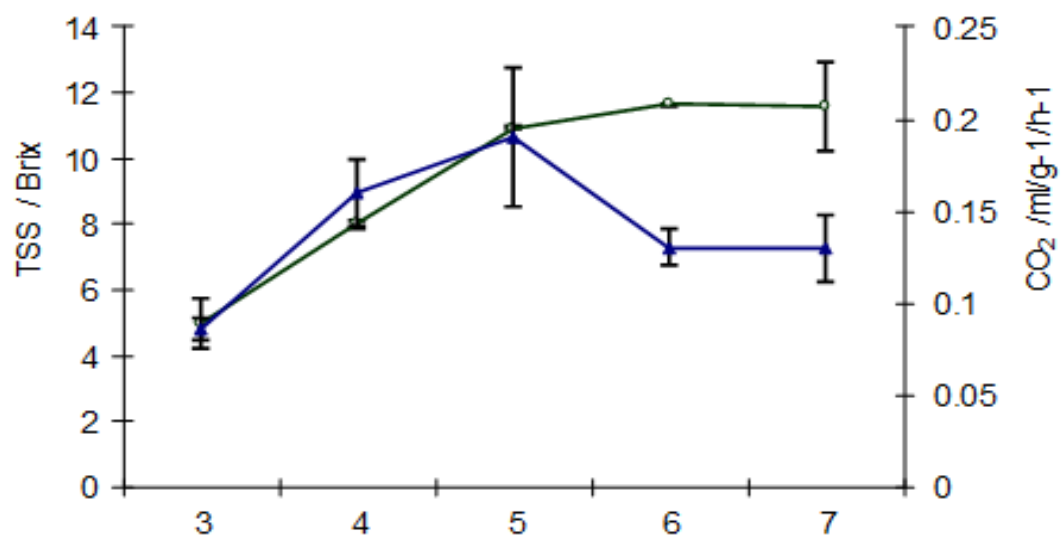

Days after harvest

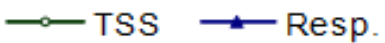

Figure 7: Variation in total soluble solids content (TSS) and rate of respiration (Resp.) from the day 3 after harvest, up to day 7 in fruits of M. zeylanica.

Lanka. Antifungal gallotannins which are found in the peel of $M$. indica are present in relatively high concentrations in the peel of $M$. zeylanica and may have contributed towards its resistance to postharvest fungal pathogens. $M$. zeylanica follows a climacteric pattern of respiration and the flesh is sweet to taste with acceptable TSS value.

\section{ACKNOWLEDGEMENTS}

The authors wish to acknowledge with thanks the willing assistance provided by P.G. Tharindu for formatting the photographs appearing in the manuscript.

\section{DECLARATION OF CONFLICT OF INTEREST}

Authors declare that they have no conflict of interest.

\section{AVAILABILITY OF RAW DATA}

Only printable images are included. However, the raw data is available upon request.

\section{REFERENCES}

Adikaram, N., Karunanayake C. and Abayasekara, C. (2010). The role of pre-formed antifungal substances in the resistance of fruits to postharvest pathogens. In, D. Prusky and M.D Gullino (Eds). Plant Pathology in the $21^{\text {st }}$ century. Springer Netherlands.

Arauz, L.F. (2000). Mango anthracnose: economic impact and current options for integrated management. Plant Disease 84: 600-610. DOI: https://doi.org/10.1094/ PDIS.2000.84.6.600.

Ariyarathne, W.A.M.P, Yakandawala, D., Samuel, M.R. and Wijesundara, S. (2017). Evaluating the occurrence and conservation status of Sri Lankan species of Anacardiaceae. Ceylon Journal of Science 46(2): 5967. DOI: http://doi.org/10.4038/cjs.v46i2.7430.

Cojocaru, M., Droby, S., Glotter, E., Goldman, A., Glottlieb, H., Jacoby, B. and Prusky, D. (1986). 5-(12-heptadecenyl)-resorcinol, the major component of the antifungal agent from the peel of mango fruit. Phytochemistry 25: 1093-1095.

Dassanayake, M.D. and Fosberg, F.R. (1983). A Revised Handbook of the Flora of Ceylon. Volume IV. Amerind Publishing Co. Pvt Ltd., New Delhi.

Dhanarisi, H.K.I., Jayatilake, J.A.M.S and Adikaram, N.K.B. (2014). In vitro antimicrobial activity of leaf extracts of Mangifera zeylanica. Sri Lanka Journal of Endogenous Medicine 4(2): 303-308.

Dodd, J.C., Estrada, A. B., Matcham, J., Jeffries, P. and Jeger, M.J. (1991). The effect of climatic factors on Colletotrichum gloeosporioides, causal agent of mango anthracnose, in the Philippines. Plant Pathology 40(4): 568-575.

Droby, S., Prusky, D., Jacoby, B. and Goldman, A. (1986). The presence of an antifungal compound and its relation to the latency of Alternaria alternata in unripe peels of mango fruits. Physiological and Molecular Plant Pathology 29: 173-183.

Ediriweera, M.K., Tennakoon, K.H., Samarakoon, S.R., Thabrew, I and De Silva, E.D. (2016 a). A study of the potential anticancer activity of Mangifera zeylanica bark: Evaluation of cytotoxic and apoptotic effects of the hexane extract and bioassay-guided fractionation to identify phytochemical constituents. Oncology Letters 11(2): 1335-1344.

Ediriweera, M.K., Tennakoon, K.H., Adhikari, A., Samarakoon, S.R., Thabrew, I and de Silva, E.D. (2016 b). New halogenated constituents from Mangifera zeylanica Hook.f. and their potential anti-cancer effects in breast and ovarian cancer cells. Journal of Ethnopharmacology 189: 165-174.

Ediriweera, M.K., Tennakoon, K.H., Samarakoon, S.R., Adhikari, A., Thabrew, I and de Silva, E.D. (2017). Isolation of a new resorcinolic lipid from Mangifera zeylanica Hook.f. bark and its cytotoxic and apoptotic potential. Biomedicine and Pharmacotherapy 89: 194-200. 
Ekanayake, G., Abeywickrama, K., Daranagama, A. and Kannangara, S. (2019). Morphological characterization and molecular identification of stem-end rot associated fungal species isolated from 'Karutha colomban' mango fruit in Sri Lanka. The Journal of Agricultural Science -Sri Lanka 14(2): 120-128.

Harill, R. (1998). Using a Refractometer to Test the Quality of Fruits and Vegetables. (2nd ed.). Keedys Villle, Madagascar: Pink Noll Publishing.

Hassan, K.M., Dann, E.K., Irving, D.E and Coates, L.M. (2007). Concentrations of constitutive alk(en) ylresorcinols in commercial mango varieties and resistance to postharvest anthracnose. Physiological and Molecular Plant pathology 71(4-6): 158-165.

Johnson, G.I., Mead, A.J., Cooke, A.W. and Dean, J.R. (1992). Mango stem-end rot pathogens-fruit infection by endophytic colonization of the inflorescence and pedicel. Annals of Applied Biology 120: 225-234.

Johnson, G., Cook, T and Mead, A. (1993). Infection and quiescence of mango stem-end rot pathogens. Proceedings IV international Mango symposium in Acta Horticulturae. 341.

Kays, S.J. (1991). Postharvest Physiology of Perishable Plant Products. New York, Van Nostrand Reinhold.

Karunanayake, K.O.L.C., Sinniah, G.D., Adikaram, N.K.B. and Abayasekara, C.L. (2014). Cultivar differences in antifungal activity and the resistance to postharvest anthracnose and stem-end rot in mango (Mangifera indica L.). Australasian Plant Pathology 43: 151-159. DOI: https://doi.org/10.1007/s13313-013-0257-4.

Karunanayake, L.C., Adikaram, N.K.B., Kumarihamy, B.M.M., Bandara, B.M.R. and Abayasekara C.L. (2011). Role of antifungal gallotannins, resorcinols and chitinases in the constitutive defence of immature mango (Mangifera indica L) against Colletotrichum gloeosporioides. Journal of Phytopathology 159: 657-664. DOI: https://doi.org/10.1111/j.14390434.2011.01818.x.

Karunanayake, L.C., G.D. Sinniah., N.K.B. Adikaram and C.L. Abayasekara (2015). Retention of latex after harvest enhances mango (Mangifera indica L.) fruit resistance and reduces anthracnose and stem-end rot. Australasian Plant Pathology 44(1): 113-119. DOI: https://doi.org/10.1007/s13313-014-0330-7

Komala Vithanage, I.S., Adikaram, N. and Yakandawala, D. (2014). Molecular and morphological characterization of Colletotrichum causing mango anthracnose in Sri Lanka. Proceedings of the Peradeniya University International Research Sessions, University of Peradeniya, Sri Lanka, Pp: 572.

Marques, M.W., Lima, N.B., de Morais, M.A., Michereffe, S.J., Phillips, A.J.L and Camara, M.P.S. (2013). Botryosphaeria, Neofusicoccum, Neoscytalidium and Pseudofusicoccum species associated with Mango in Brazil. Fungal Diversity 61: 195-208.

MOE (2012). The National Red List 2012 of Sri Lanka; Conservation Status of the Fauna and Flora. Ministry of Environment, Colombo, Sri Lanka. Viii +476 .

Medagoda, I. and Jayawardene, S.D.G. (1997). Status report on genetic resources of mango in Sri Lanka. Horticultural Crop Research and Development Institute,
Department of Agriculture, Gannoruwa, Sri Lanka.

Nakasone, H.Y. and Paull, R.E. (1998). Tropical Fruits. CAB International, Wellingford, Oxon, United Kingdom, 445.

Nisansala, Y.M.C., Jayakody, L.K.R.R., Sarananada, H.A and Somarathne, S. (2015). Effect of preharvest potassium treatment on stem-end rot disease development in Mango (Mangifera indica L) cv. Tom EJC during fruit ripening. Sabaragamuwa University Journal 14(2): 119-132. DOI: http://doi.org/10.4038/ suslj.v14i2.7700.

Petrini, O. (1986). Taxonomy of endophytic fungi of aerial plant tissues. In: N.J.H. Fokkema and J. van den Heuvel (Eds.) Microbiology of the Phallosphere, Cambridge University Press, Cambridge, UK. Pp: 175-187.

Prusky, D. and Keen, N.T. (1993). Involvement of antifungal compounds in the resistance of subtropical fruits to fungal decay. Plant Disease 77: 114-119. DOI: 10.1094/PD-77-0114.

Samane, M., and Mohoammad, H. (2012). Effect of essential oils on postharvest decay and some quality factors of peach (Prunus persica var. Redhaven. Journal of Biological Environmental Science 6: 147-153.

Senevirathna, H.D.A.A., de Silva, E.D., Wijayarathna, C.D. and Wijesundara, R.L.C. (2015). Antimicrobial potential of the endophytic fungal extracts of Mangifera zeylanica (Anacardiaceae) an endemic plant of Sri Lanka against selected pathogenic bacterial species. Proceedings of the $35^{\text {th }}$ Annual Sessions of the Institute of Biology, Sri Lanka. 58.

Trakunyincharoen, T., Cheewangkoon, R., To-anun, C., Crous, P.W., van Nikerk, J.M. and Lombard, L. (2014). Botryosphaereaceae associated with diseases of mango (Mangifera indicia). Australasian Plant Pathology 43(4): 425-438. DOI: 10.1007/s13313-014-0284-9.

Weeraratne, W.A.P.G., Samarajeewa, P.K. and Nilanthi, R.M.R. (2005). Characterization of mango germplasm using random amplified polymorphic DNA and morphological markers. Annals of the Sri Lanka Department of Agriculture 7: 289-300. 